\title{
The Effectiveness of Imagine Technique on the Ability to Write Poetry Towards the Tenth Grade Students of SMA Negeri 2 Tungkal Jaya
}

\author{
Dessy $\operatorname{Wardiah}^{1 *}$, Komarudin ${ }^{1}$ \\ ${ }^{1}$ Universitas PGRI Palembang \\ *Corresponding Author. E-mail:dessywardiah77@gmail.com
}

\begin{abstract}
The question that to be solved in this research, was there any effect of the imagine technique on the ability to write poetry towards the tenth grade students public of High School (SMA Negeri) 2 Tungkal Jaya? This research used an experimental method with a posttest design (final result) in the control and the experimental class. This study aims to determine and describe the effectiveness of the imagine technique in the ability to write towards the tenth grade students of SMA Negeri 2 Tungkal Jaya. The sample in this study were 29 students of class X IIS 2 as the control class and class X MIA 1 which consisted of 29 students as the experimental class. The data analysis technique used was the test data analysis technique. Based on the results of the study, it shows that there was an effect of imagine learning techniques on the ability to write poetry towards the tenth grade students of SMA Negeri 2 Tungkal Jaya, which was shown by the t-test value obtained of 5.708 with a level $(000>0.05)$. Due to the significant level $0.18>0,05$, thus Ho was rejected and Ha was accepted.
\end{abstract}

Keywords: Imagine Technique (Visual Delusion), Ability, Writing Poetry.

\section{INTRODUCTION}

Etymologically, the term literature can be defined as a collection or thing that is used as a teaching tool, manuals, and teaching instructions. Susastra comes from the su + literary form. The word literature comes from the Sanskrit language, which comes from the root word sas which in the derivative verb means "to direct, teach, give instructions, or instructions", while the tra suffix indicates "tool, means". Literature is divided into two, namely written literature and oral literature. As stated by Sumayana [1], that literature can be in the form of written literature and oral literature. Written literary work is text in the form of writing or story. Meanwhile, oral literature is the text in the form of oral and passed down orally from generation to generation.

Literature can describe the heart of the poet. This happens because the handwriting of the poet is accompanied by his emotions and feelings as a poet. Literature is very interesting in terms of its words, so there are several types of literature that have emerged in Indonesia, namely poetry, prose and drama. Poetry literature has appeared since ancient times. Poetry is one of the literary genres, contains expressions of a poet's feelings, contains rhymes and rhythms, and is expressed with careful word choice. Meanwhile, prose is in the form of a fictional story and a combination or collaboration between thoughts and feelings. Prose in the literary sense is also called fiction (imaginary story). And drama is a literary work that has a very high stimulation of creativity, taste, and initiative. Meanwhile, according to Kosasih quoted from [2], poetry is a form of literature that uses beautiful words and is rich in meaning.

Poetry cannot be separated from writing activities. Writing poetry is a form of manifestation of a poet's handwriting which has a certain meaning based on the expression of the poet's heart and soul in his work. As stated [3], that writing is a skill to express, express, the contents of the heart in written form. By using the right diction and language style, poetry will have good values from the way it is written. 
Teaching poetry writing material in schools is very important because the art of writing poetry is something that must be learned for a student. In the process of teaching poetry to be carried out, the researcher uses the imagine technique (visual imagery) to find the data to be presented. Imagine means an imagination or delusion performed by students in appreciating their writing in the form of poetry. As stated by Muhibuddin [4], that etymologically, imagination comes from English, imagination which has Latin roots, or description. In Indonesian, imagination is defined as imaginary or imaginary. Imagining or imagining is meant to create something in your mind that is not or hasn't happened yet. Imagination actually refers to the notion of creative thinking, "creative thinking" to create and produce something. By imagining, a person actively thinks, understands, and analyzes something new. A strong imagination will further increase creativity to create good, easy to understand, beautiful and creative writing too [5].

Interest in writing poetry for students of SMA Negeri 2 Tungkal Jaya is still very minimal and low. In addition, there are still many students who do not understand how to write good poetry and students still have difficulty how to use good and correct diction or language style. This data was obtained based on interviews between researchers and Indonesian language teachers at SMA Negeri 2 Tungkal Jaya. For this reason, the reason why the researcher chose the Tungkal Jaya 2 Public High School as the object of research is because at this time in this school many students do not understand how to write good poetry, students still have difficulty how to use diction or language style good and right. The low interest in writing poetry and the lack of knowledge of poetry are the main factors in the problem of writing poetry. Therefore,

Etymologically, imagination comes from English, imagination which has Latin roots, or a picture. In Indonesian, imagination can be interpreted as imaginary or imaginary [6]. Imagining or imagining is meant to create something in your mind that is not or hasn't happened yet. Imagination actually refers to the notion of creative thinking, "creative thinking" to create and produce something. By imagining, a person actively thinks, understands, and analyzes something new. A strong imagination will further increase creativity to create good, easy to understand, beautiful and creative writing as well [7]. Furthermore Esten [8], provides an explanation that imagination is the power of imagination, the power of fantasy, and the power of imagination but not delusion or daydream. The power of the imagination is still rooted in facts and experiences. Therefore it does not need to be connected with objective facts or actual events.

Writing is a process of depicting graphic symbols depicting a language that someone understands so that other people can read the graphic symbols. If they understand the language and symbols, writing is not just using letters, but there is a message the writer brings through the painting of these symbols [9]. The ability to write which has so many comprehensive roles in training children's creativity and intelligence is starting to be less attractive in an instantaneous world, even though writing skills are indispensable in developing students' cognitive and creative potential [10].

Writing poetry is not a skill, although several books have described the steps of writing poetry. If making pottery art can be scheduled in a day to produce five works, not with poetry. Poetry requires a special supplement, namely "poetic moments". Poetic moments are those when the poet gets an idea. This idea cannot be scheduled, it must be thought of so that it is different from existing works, fresh, and gives a certain impression to the audience. As per the words, the meaning used hits and the atmosphere is built accordingly [11]. Armariena [12] also states that writing is an ability that is active and productive in producing writing that is obtained through a process of continuous learning and practice. Writing poetry is a skill to express, express the heart's contents in written form [13].

\section{METHODS}

The research method is a scientific way of obtaining data for specific purposes and uses [14]. The method used in this research was the experimental method. The experimental method is a method in which the calculation method requires using numbers, starting from data collection, interpretation and appearance of the results [15].

\section{RESULTS AND DISCUSSION}

In the analysis of the results of this study, part of the description of the implementation of research data will be presented from the results of documentation and written poetry writing tests conducted by researchers at SMA Negeri 2 Tungkal Jaya. The results shows that the data description of the poetry writing test for students carried out in class $\mathrm{X}$ totaling 58 students sampled from two classes, namely the control class and the experimental class with 29 students in the experimental and control class. This research was conducted on 5 October 2020 to 10 October 2020 and this research was conducted face-to-face, but this research was 
carried out according to government recommendations by using a mask because it is still in a state of the Covid-19 pandemic even though the Tungkal Jaya area is still in the green zone.

\section{Description of the Control Class Poetry Writing Test Data}

The learning outcome data was taken from the test scores given to students after the provision of writing poetry material in the control class (X IIS 2) SMA Negeri 2 Tungkal Jaya. Before being given a poetry writing test in the control class, students first took part in the lesson using the lecture method or not using the imagine technique (no treatment). This test was given with the aim of finding out the effectiveness of the imagine technique on the ability to write poetry in class X SMA Negeri 2 Tungkal Jaya.

In the presentation of the analysis of the data description of the poetry writing test in the control class, it can be seen that the final test score of the control class in writing poetry that gets 46 is 3 people, 1 person gets 50,1 gets 54 , who gets 1 person has a value of 55,2 people get a score of 56,1 person gets a score of 60,1 person gets a score of 63,1 person gets a score of 66,2 people get 671 person, who gets a score of 70 is 1 person, who gets a value of 72 as much as 1 person, who gets a value of 73 as much as 1 person, who gets a score of 74 as much as 2 people, who gets a score of 75 as many as 2 people, who gets a score of 77 as many as 1 person , 1 person obtaining a score of 79,1 person obtaining a value of 82 and 2 obtaining a score of 85 .

From the total score of the final test in the control class, the total final text score is 1964, then the number of tests is divided by the number of students who took the test as many as 29 students in the control class so that the control class average score is 67.72. This data is obtained based on research at SMA Negeri 2 Tungkal Jaya.

\section{Poetry Writing Test Data Description for Experiment Class}

The learning outcomes data were taken from the test scores given to students after the provision of material for writing poetry in the experimental class at SMA Negeri 2 Tungkal Jaya. Before being given a poetry writing test in the experimental class, students first took part in a poetry writing lesson using the lecture method and visual imagery techniques. This test was given with the aim of finding out the effectiveness of the imagine technique on the ability to write poetry in class X SMA Negeri 2 Tungkal Jaya.
In the presentation of the data description analysis of the poetry writing test in the experimental class, it can be seen that the final test score in the experimental class in writing poetry that obtained a score of 65 was 3 people, 1 person got a score of 68,1 person got 69 points 1 person has a value of 70, 1 person gets a score of 73,2 people get a value of 76,1 person gets a score of 76,3 people get a score of 80,3 people get a score of 81 as many as 1 person, 2 people who get a score of 82,1 person who gets a score of 85,2 people who get a score of 86,1 person who gets a score of 87,2 people. 2 people who get a score of 90 and 1 person who gets a score of 95 . From the overall test scores in the experimental class, the final test scores were 2274, then divided by the number of students who took the test, so that the class average score was 78.41.

Therefore, based on the results of the analysis above, writing free poetry in class $\mathrm{X}$ SMA Negeri 2 Tungkal Jaya by using the imagine technique can increase student activity in learning. After receiving treatment using the imagine learning technique (visual imagery), the average score of the two differentiating values between the control class and the experimental class class X SMA Negeri 2 Tungkal Jaya in writing free poetry, namely for the control class is 67.72 and for the class experiment of 78.41. This is proven by the average of the two classes in writing free poetry, there is an effectiveness in the imagine learning technique given to class $X$ students of SMA Negeri 2 Tungkal Jaya.

Then the hypothesis testing was conducted. The T test value obtained was 5.708 with a level $(000>0.05)$. Due to the significant level $0.18>0.05$, based on these criteria it is found that $\mathrm{HO}$ is rejected, $\mathrm{Ha}$ is accepted. Thus, there is a difference in the mean between the experimental class and the control class.

The success in researching the effectiveness of the imagine technique on the ability to write poetry in class X SMA Negeri 2 Tungkal Jaya is due to the presence of an Indonesian language subject teacher, Mrs. Setiyani, S.Pd. which helps and guides researchers during the teaching process in class or during classroom research. The principal of SMA Negeri 2 Tungkal Jaya, Mr. Musta'in, S.Pd., MM, has always provided support, motivation, direction and guidance to researchers. In addition, the researchers and students are very close and have very close kinship so this is very helpful during the research process. 


\section{CONCLUSION}

Based on the results of the analysis in this study, it can be seen that the treatment given to the experimental class and control class through the post-test score of the experimental class is 78.41 and the control class is 67.72 . This means that the experimental class population is better than the control class. The $\mathrm{T}$ test value obtained is 5.708 at the level $(000>0.05)$. Due to the significance level $0.18>0.05$, based on these criteria it is found that $\mathrm{HO}$ is rejected, $\mathrm{Ha}$ is accepted. Thus, there is a difference in the average between the experimental class and the control class. Therefore, the researcher can conclude that "There is an Influence of the Effectiveness of Imagine Techniques on the Ability to Write Poetry of Class X Students of SMA Negeri 2 Tungkal Jaya. It is known that there is an influence in the use of an imagine learning technique (visual imagery) on the ability to write poetry of class $\mathrm{X}$ students of SMA Negeri 2 Tungkal Jaya. So the imagine learning technique (visual imagery) on students' poetry writing ability can be better for the learning process to write poetry so that students can better understand how to write good poetry and can receive or digest learning material to write poetry better, and can add knowledge. in understanding in finding ideas and thinking imaginatively and creatively in developing poetry writing skills for students.

\section{REFERENCES}

[1] Sumayana, Y. (2017). Learning Literature in Elementary Schools Based on Local Wisdom (Folklore), page: 24-25. Elementary School pulpit.

[2] Hetilaniar. (2019). The Effect of the Jumput Strategy on the Ability to Read Poetry of Class X Students of SMA Negeri 10 Palembang, page 15. Lecturer at PGRI Palembang University.
[3] Azizah, A. (2015). Learning To Write Poetry Using BrainWriting Techniques For Class V Elementary / MI Students, page: 2. Scientific Journal.

[4] Muhibuddin, M. (2011). The Power of Imagination. Yogyakarta: Blue Book.

[5] Nurgiyantoro, B. (2013). Theory of Fiction Assessment. Yogyakarta: Gadjah Mada University Press.

[6] Muhibuddin, M. (2011). The Power of Imagination. Yogyakarta: Blue Book.

[7] Nurgiyantoro, B. (2013). Theory of Fiction Assessment. Yogyakarta: Gadjah Mada University Press

[8] Esten. (2013). Introduction to Literature Theory and History. Bandung: Angkasa Bandung Publisher.

[9] Tarigan, HG. (2008). Writing as a Language Skill. Bandung: Space.

[10] Wardiah, D. (2017). The Role of Storytelling in Improving Students' Writing, Reading and Emotional Intelligence Ability. Lecturer at PGRI Palembang University, 10. http: //dx.doi.org/10.31851/wahanadidaktika.v1 $5 \mathrm{i} 2.1236$

[11] Indriyana, H. (2019). The Art of Writing Poetry. Yogyakarta: Gambang Book of Culture.

[12] Armariena, DN. (2018). Writing Poetry on the Themed Local Culture Using the Student's Imagination Suggestion Model, page: 1. Lecturer at PGRI Palembang University.

[13] Azizah, A. (2015). Learning To Write Poetry Using BrainWriting Techniques For Class V Elementary / MI Students, page: 2. Scientific Journal.

[14] Sugiyono. (2015). Quantitative Research Methods, Qualitative and R \& D. Bandung: Alfabeta.

[15] Arikunto, S. (2006). Research Procedure A Practical Approach. Jakarta: PT Rineka Cipta. 